\title{
Modelling the impact of energy policies on the Philippine economy: carbon tax, energy efficiency, and changes in the energy mix
}

\author{
Helen Cabalu and Paul Koshy \\ Curtin University \\ Erwin Corong \\ Purdue University \\ U-Primo E. Rodriguez and Benjamin A. Endriga \\ University of the Philippines, Los Baños
}

\begin{abstract}
As part of its global obligations to responding to climate change, the Philippines is committed to limiting future emissions growth through policy interventions such as funding research on mitigation and direct regulation of energy efficiency requirements. The Philippines is also interested in extensions of such policies, including the use of carbon taxes, measures to enhance energy efficiency, and changes to the country's electricity generation mix.
\end{abstract}

This paper develops a computable general equilibrium (CGE) model of the Philippine economy to analyse the effects of such climate change policy options in the period to 2020. The modelling results indicate that given the current level of development in the Philippine electricity generation and transport sectors, even relatively modest measures have marked impacts on emissions with marginal economic impacts. A carbon tax of \$US5 per a tonne, results in a 9.8\% reduction in emissions and a $0.5 \%$ reduction in GDP from baseline levels to 2020 . Similarly, a $2 \%$ increase in energy efficiency throughout the Philippine economy results in an $8.5 \%$ reduction in emissions and $0.6 \%$ reduction in GDP compared to the underlying baseline of no policy response. Finally, a $10 \%$ shift in the coal-fired generation capacity results in an $11.0 \%$ reduction in emissions with GDP in fact increasing by $1.9 \%$ over baseline levels.

JEL: C68; F64; O44; Q56

Keywords: climate change; CGE modelling; Philippine policy response; 
Acknowledgement: The authors of this paper would like to acknowledge the financial assistance provided by AusAID for the Public Sector Linkages Program (PSLP) project, Modelling Policy Responses to Climate Change: Implications for Sustainable Growth and Development in the Philippines, Agreement Number 57049. 


\section{Introduction}

There is broad consensus that climate change is a reality and that its causes are significantly anthropogenic in origin, with the IPCC (2007) noting that mean, maximum, and minimum temperatures have increased $0.14^{\circ} \mathrm{C}$ per decade since 1971.

The Philippines will be particularly affected by climate change, with the country's average annual mean temperature projected to increase by $0.9^{\circ} \mathrm{C}-1.2^{\circ} \mathrm{C}$ by 2020 and $1.7^{\circ} \mathrm{C}-3.0^{\circ} \mathrm{C}$ by 2050 (UNFCCC 2007; World Bank 2010a). Issues with great pertinence to the Asia Pacific, such as increased typhoon activity and sea level rise (World Bank, 2010a) or food security (Bandara and Cai, 2014), are now emerging as critical challenges in the Philippines. For instance, the projected impacts of climate change on the Philippines include increased typhoon activity and a projected 30 centimetre rise in sea level by 2045 . This is close to the Asian Development Bank's (ADB, 2009) 'low scenario' which indicates these rises would affect 2,000 ha and around 500,000 people.

Commencing in 1991 the Philippines has enacted a wide range of climate change-related policies and has taken an active role mitigating aspects of climate change in the application of the Clean Development Mechanism. The Inter-Agency Committee on Climate Change was established in 1991 and in 1992 in response to its Earth Summit commitments, the Philippine Council for Sustainable Development was created. The Philippines ratified the Kyoto Protocol 
in 2003, leading to the formation of the Presidential Task Force on Climate Change Adaptation and Mitigation and the Advisory Council on Climate Change (Rincon and Virtucio, 2008).

Given the pace of international developments and experiences with climate-related natural disasters, the Philippines has increasingly focused on its national response, culminating in the passing of the Climate Change Act of 2009, the establishment of the Climate Change Commission, the introduction of the National Framework Strategy on Climate Change in 2010 and creation of the National Climate Change Action Plan 2011-2028.

It is likely that further international discussions at the United Nations Framework Convention on Climate Change (UNFCCC) Conferences of Parties (COPS 21) in Paris in December 2015 and further developments at the international or regional level will see the Philippines adopt emerging policy responses to climate change. In this context, the modelling of potential responses becomes crucial as any policy shifts will have implications for the Philippine economy.

The main aim of this paper is to evaluate and analyse the potential short and long-term economic effects on the Philippine economy of policy responses to climate change, including the introduction of a carbon tax, improvements in energy efficiency and changes in the energy mix using a computable general equilibrium (CGE) model referred to as the PHILGEM-E model. The remainder of this paper is organised as follows. Section 2 provides a brief overview of the use of CGE models in climate change policy and discusses the structure of PHILGEM-E model. 
Section 3 outlines the results from the modelling of three policy responses while Section 4 discusses their implications. Section 5 concludes the paper.

\section{Methodology}

\subsection{The use of CGE models in climate change policy}

CGE models are widely used tools in economic analysis. They have been applied to the evaluation of a range of potential impacts including on welfare, outputs, prices, consumption, international trade, income distribution, poverty, pollution, and other indicators of policy actions and events in international trade, government spending and taxation, and the environment (for a discussion of these issues see Cabalu and Rodriguez, 2007; and Cororaton and Cockburn, 2007). CGE models represent the entire economic systems and are able to accommodate macroeconomic feedbacks through changes in the price of goods and costs of production when policy shock occurs. The appeal of these models is also based mainly on their ability to combine economic theory with actual data of the entire economic system. It is therefore able to generate insights on the effects of policies and events in a context that is a step closer to the real world without severely compromising economic theory. CGE models have been used extensively in the analysis of climate change with a particular focus on the impact of mitigation efforts. These include static and dynamic versions of multi-country and country-specific models (Fujimori et al., 2014a). 


\subsubsection{International CGE models on mitigation}

CGE models focussed on mitigation examine the impacts on economies of reducing greenhouse gas emissions. Reflecting the wide range of potential policy levers, CGE models have evaluated climate change mitigation in a number of ways. These include the use of taxes, trading of emission permits, abatement investments, and quantitative limits on emissions. Multi-country and country-specific models have been used in this analysis. Recent examples of studies that used multi-country models include: Fujimori et al. (2014b), Timilsina and Mevel (2013), Calzadilla et al. (2011), Nurdianto and Resosudarmo (2014), Klepper and Peterson (2006), Babiker (2005), and Bohringer (2000), with these studies drawing on earlier research from studies such as Whalley and Wigle (1991). Specific models have been developed for a number of countries including Australia (Allen Consulting Group, 2006; Adams and Mai, 2002; McDougall, 1993), Austria (Breuss and Steininger, 1998), China (Garbaccio et al., 2010), India (Pal et al., 2015; Rana, 2003), Yusuf et al., 2010), Ireland (Jensen et al., 2003), Israel (Palatnik and Shechter, 2008), Malaysia (Jaafar and Al-Amin, 2008), Norway (Brendemoen and Vannemo, 1994; Glemsrod et al., 1992), South Africa (van Heerden et al., 2006) and Turkey (Telli et al., 2009).

Carbon taxes have been prominent in policy discussions to reduce the quantity of carbon dioxide emissions and evaluating the impacts of taxes on carbon emissions are among the most popular measures in CGE models. Some of these studies based emission cuts on existing or proposed agreements and targets. For example, Palatnik and Shechter (2008), Klepper and Peterson (2006), Babiker (2005), Bollen et al. (2000) and Bohringer (2000) based their targets 
on the Kyoto protocol while Yusuf et al. (2010) focused on the Indonesian action plans submitted to the Copenhagen Accord. There are also studies which used rather arbitrary targets for emission cuts. Examples include McDougal (1993) and van Heerden et al. (2003) which imposed a tax of $\$ 25$ and $\$ 5$ per ton of carbon dioxide emissions, respectively. In some cases, the amount of the tax was calibrated to generate a predetermined level of emissions reductions. For example, Garbaccio et al. (1998) used a tax of 9 yuan/ton of carbon in the first year of the simulation run in order to achieve a $5 \%$ cut in emissions. Another example is that of Klepper and Peterson (2006), who estimate the magnitude of carbon taxes for European member states that are necessary to meet their Kyoto targets. The simulation results indicate that the amount of tax ranges from 5 euros (France and Greece) to 60 euros (Denmark and Ireland) per ton of $\mathrm{CO}_{2}$ emission.

The direct impact of carbon taxes is through price increases where emissions-intensive goods will have higher market prices and/or lower profits as firms pass on to consumers the cost of reducing emissions. To reduce the burden of the abatement costs on consumers, some firms react by implementing conservation measures, energy efficient investments, fuel and product switching, and changing the economic production and consumption structures (Baranzini, et al., 2000).

There is evidence from other studies (OECD 1994, 1996, 1997; Jaffe et al., 1995) that due to carbon or energy taxes, some energy-intensive firms relocate investment and production to other countries while other firms merely shut down or reduce capacity. In the case of the 
Philippines, firms react by changing economic production structures by switching from coal to natural gas as a production fuel, and reducing the level of output as a result of lower household income and hence domestic consumption and demand. This leads to a fall in GDP and price. The distributional impact of carbon taxes is another major issue in determining the policy's acceptability. Arising from this distributional impact are two key financial issues (OECD, 1994). Firstly, who gains more and who gains less from the environmental benefit? Secondly, who pays more or who pays less for the financial effects such as compliance or implementation costs? Most of the previous studies (Poterba, 1991; OECD, 1994; OECD, 1996; Baranzini et al., 2000; Boyce at al., 2005; Yusuf and Resosudarmo, 2015; Corong 2007; 2008) focus on the distributional impacts of financial costs and measure them across different dimensions such as the distribution between households over different income groups; between different household types; between rural and urban households and between different generations.

The majority of the studies focus on the distributional impact across different income groups and confirm the regressivity of the carbon tax. That is, lower income groups pay disproportionately more as they spend a larger fraction of their available income on energyintensive commodities than high-income groups. However, a study on China by Boyce et al. (2005) and on Indonesia by Yusuf and Rososudarmo (2015) suggest that even without revenue recycling, the effect of a carbon tax is progressive when results are primarily driven by differences between urban and rural expenditure patterns, particularly where rural areas are poor. Rural households consume less energy-intensive (manufactured) products with energy use fuelled by firewood and other such products. Another driver of Boyce et al.'s results is the 
impact of carbon tax on household income through changes in commodity and factor prices and employment caused by the changes in output composition.

There are other market based instruments, aside from a carbon tax, that can create the desired effects of reducing emissions. Telli et al. (2008) examine the impacts of taxes on energy inputs coal, petroleum, gas and electricity. The study finds that the model's $10 \%$ energy tax is equivalent to a $14.2 \%$ reduction in carbon dioxide emissions by the year 2020 . Another study by McDougall (1993) explores energy taxes on fossil fuels and taxes on refined petroleum products. A comparison of four types of taxes is also presented by van Heerden et al. (2003).

An important concern in the analysis is how the revenues from the tax changes are used in the economy. Carbon taxes offer an additional source of revenues for the government. The manner, in which these revenues are used in the model, if at all, will affect the conclusions of the study. Breuss and Steininger (1998) present various scenarios in which carbon tax revenues are used in the economy, including compensating labour costs and stimulating investments. Another South African study by van Heerden (2003) explores recycling tax revenues by means of reducing (a) direct taxes on labour and capital, (b) indirect taxes on households, and (c) food prices.

CGE models have also been used in the analysis of emissions trading. The basic principle behind such a mechanism is the sale and purchase of previously allocated emission quotas between 
industries or countries. ${ }^{1}$ Bollen et al. (2000) for example examine the impacts of the free trade of emission rights among Annex 1 countries in order to comply with their collective target under the Kyoto Protocol. ${ }^{2}$ The paper then compares the results with a scenario in which carbon taxes are used in order to meet the targets of the individual countries. Klepper and Peterson (2006) also assess the impacts of various scenarios on emissions trading schemes in the European Union. The scenarios vary on the extent to which the Clean Development Mechanism (CDM) and Joint Implementation (JI) mechanisms are used by the countries. ${ }^{3}$

While the principle behind emissions trading is simple, CGE models have attempted to capture a number of more complex schemes. Bohringer (2000) evaluates the extent to which emissions trading can take place among Annex 1 countries/regions in achieving the targets of the Kyoto protocol. ${ }^{4}$ In one scenario, the paper examines the impacts of international trade in emission rights among Annex 1 countries. Another scenario prohibits trade among countries but allows it to occur within each country. The paper also implements a type of middle ground scenario where there are limits on the amount of emission permits that can be traded internationally. In this experiment, Annex 1 countries may only buy or sell emission permits that do "not exceed

\footnotetext{
${ }^{1}$ A more detailed description of emissions trading and its features relative to other instruments (e.g. carbon taxes, emission quotas) is provided in chapter 8 of Cline (1992).

${ }^{2} \mathrm{~A}$ list of the Annex 1 countries may be found in the website of the United Nations Framework Convention on Climate Change (http://unfccc.int/kyoto_protocol/items/3145.php)

${ }^{3}$ Klepper and Peterson (2006) briefly describe these mechanisms as the ability of "European facilities covered by the ETS [Emission trading scheme] to carry-out emission curbing projects in other Annex I countries (JI) and nonAnnex I countries (CDM) and to convert the credits earned into emissions allowances under the ETS" (p. 1). ${ }^{4}$ The website of the United Nations Framework Convention on Climate Change (http://unfccc.int/kyoto protocol/items/3145.php) states Annex B countries represent members of Annex I countries except Belarus and Turkey.
} 
$5 \%$ of the weighted average of base year emissions and the assigned Kyoto emission budget" (p. 782).

Pinto and Harrison (2003) illustrate how the impacts are likely to be affected when there are differences in the extent of participation in emissions trading. ${ }^{5}$ As a whole, the scenarios differ in (a) country commitment to abatement (all OECD countries compared to United States and European Union only), and (b) the presence of the Intergovernmental Panel on Climate Change (IPCC) in the negotiations.

Another measure examined in CGE models is the increase in investments in green technologies. Telli et al. (2008), for example, examine the impacts of energy-saving investments on activities that will reduce emissions from energy inputs. The study also evaluates different schemes for financing investments such as taxes on polluting energy inputs and/or foreign aid. A related measure is the introduction or promotion of cleaner energy sources. An example here is the study of Rana (2003) which examines the impacts of lower costs of solar power on carbon emissions.

Babiker (2005), Wing (2009) and Whalley and Wigle (1991) provide an analysis of the impacts of emission cuts without identifying a specific action (i.e., taxes, trading, etc). The results from these studies can be interpreted as the impacts of simple quantitative restrictions on emissions.

\footnotetext{
${ }^{5}$ The paper also compares the results in a setting where there is no emissions trading.
} 
The controlled setting of CGE models offer a means by which a comparative analysis of the different instruments can be made possible. McDougall (1993) for example uses the model to compare three possible instruments - energy taxes on fossil fuels, carbon taxes, and taxes on refined petroleum products. Telli et al. (2008), on the other hand, explore the role of various financing schemes - taxes and foreign aid - for energy-saving investments.

The extensive use of dynamic CGE models also facilitates the analysis of issues regarding the timing of the implementation of climate change policies. For example, Allen Consulting Group (2006) evaluates the impacts of early action and delayed action scenarios in achieving greenhouse gas emission targets by the year 2050. In the early action scenario, the authors assume emissions reductions take place from 2013 to 2050. On the other hand, the delayed action scenario assumes that the reduction in emissions will only begin in 2022 , which in turn requires steeper cuts in emissions in order to achieve the targets for 2050.

It is important to note that there is an abundance of studies which have a different focus but can be useful in the analysis of climate change. Adkins and Garbaccio (2002) and Kang and Kim (2004), for example, examine the impacts of trade reforms on carbon dioxide emissions and other air pollutants. To the extent that carbon taxes and trade reforms - especially the removal or reduction of import tariffs - have contrasting effects on government revenues, such studies offer an alternative mechanism by which the revenues from carbon taxes are reallocated to the rest of the economy. The study of Beghin et al. (1999) potentially offers a broader set of results as it provides links between trade integration, air pollution and health. 


\subsubsection{Philippine CGE models and climate change}

Of the Philippine CGE models that have been developed, only Corong $(2007 ; 2008)$ explicitly deal with climate change. Corong (2007) focuses on the impacts of a 385 peso/ton carbon tax (valued at 1994 prices). In separate experiments, the author also examines the impacts of a $60 \%$ reduction in nominal tariffs, and a combination of the tariff cuts and the carbon tax. Government revenues were kept constant in all simulations by adjusting income taxes. Among the key findings of the study is that the carbon tax is likely to cause a decline in aggregate output and household incomes, and an increase in poverty. However, it also finds that the $60 \%$ reduction in nominal tariffs is able to overcome the negative impacts of the carbon tax. Experiments that combine both initiatives indicate an increase in aggregate output and reduction in poverty.

The analysis in Corong (2008) was along the same lines as Corong (2007). However, the tariff reductions were based on actual changes from 2000 to 2006 and the carbon tax (100 pesos/ton) was designed to reduce carbon emissions by $1 \%$. The study also explores different scenarios on how the revenues from carbon taxes are used and alternative closure rules for the labour market.

Corong (2008) highlights four results from the analysis. First, the tariff reductions from 2000 to 2006 generate a decline in consumer prices that outweigh the increase in consumer prices caused by the carbon tax. Second, the strongest declines in consumer prices and disposable incomes occur when revenues from carbon taxes are used to reduce indirect taxes. Third, the 
reduction in poverty is smaller when the full employment assumption is relaxed in the analysis. Finally, the most favourable scenario in terms of reducing poverty and improving consumer welfare is when revenues from carbon taxes are used to cut income taxes.

The two papers above illustrate how the Philippine CGE models can be used in the analysis of mitigation policies, particularly with a carbon tax. The authors also explore mechanisms, such as trade policy and revenue recycling, to soften or overcome the negative economic impacts of the carbon tax.

It is also important to note that there are some Philippine studies which explored instruments to reduce carbon emissions without specifying climate change policy as an objective.

Dufournaud et al. (2003) and Rodriguez (2009b) show how a commercial logging ban and promoting biofuels in the Philippines can reduce carbon emissions. Inocencio et al. (2001) showed how by introducing an emissions tax on biochemical oxygen demand (BOD) can be used as a tool to implement a carbon emissions reductions. Dufournaud et al. (2003) and Inocencio et. al. (2001) also conduct experiments where changes in trade policy interact with commercial logging bans and an emissions tax.

\subsection{The PHILGEM-E model of the Philippine economy}

The CGE model employed in this paper is a modification of PHILGEM (Corong and Horridge, 2012), a single-country CGE model of the Philippine economy. PHILGEM extends the wellknown ORANI-G model which is a generic version of the ORANI applied general equilibrium 
model of the Australian economy which was first developed in the late 1970s (see Horridge, Parmenter and Pearson, 2001, for an overview). ORANI-G has been used as a launching pad for developing new CGE models for other countries including Brazil, Finland, Malaysia, South Africa, Vietnam, Indonesia, South Korea, Thailand, the Philippines, Pakistan, Denmark, Uganda, China, Taiwan, and Fiji. The extensions in PHILGEM include the introduction of multiple households and additional equations to facilitate the use of data sourced from a social accounting matrix (SAM). As a result, PHILGEM highlights the linkage between producing sectors and the rest of the economy and tracks how income is generated, distributed and transferred.

This paper focuses on a variant of PHILGEM referred to as PHILGEM-E designed for the energyeconomy-environment-trade linkages analysis. PHILGEM-E facilitates the analyses of the possible short and long-term economic effects of policy responses to climate change. Explicitly it:

(i) Allows for energy substitution in non-energy industries;

(ii) Distinguishes electricity generation by technology;

(iii) Allows the electricity sector to substitute away from carbon-intensive towards less carbon-intensive and/or carbon-free generation technologies; and

(iv) Accounts for carbon emissions associated with different fuel types and emissions generated by various agents.

The model assumes that each industry minimises costs subject to constant returns to scale (CRTS) production technology; and is a price taker for inputs and outputs. Typical of CGE 
models, it operates based on the optimizing decisions of each agent in the economy. The demand-side assumes cost minimization, whereas the supply-side assumes profit maximisation. The industry and commodity classifications of the model's database are listed in Table 1. It should be noted that the industry classification differs slightly from the commodity classification. There are 35 industries classified into: 6 agriculture; 3 mining-related; 3 processed food and beverage; 8 manufacturing industries which include petroleum refining; 7 electricity industries composed of 6 types of generation technology and an electricity distribution sub-industry; and 8 service industries which include public services.

\section{[Insert Table 1 here]}

Multi-production is confined to two industries. The first, crude oil and natural gas extraction produces natural gas and crude oil commodities. The other multi-product industry is petroleum refining which produces 5 commodities, namely: gasoline, diesel oil, fuel oil, liquefied petroleum gas, and other petroleum products. Each of the remaining 33 industries produces a unique commodity. Out of 40 commodities, 8 are classified as carbon emitting fuels, while 3 commodities are classified as margin commodities. Margin commodities are required to facilitate the flows of other commodities from producers (or importers) to users. In addition, the database classifies representative households into 'urban' and 'rural', while labour is disaggregated into 'skilled' and 'unskilled'.

A graphical representation of the underlying input-output table for the model is presented in Figure 1. The basic structure of the PHILGEM-E model and the columns in this absorption matrix contain the areas of demand from: 
(1) Domestic producers divided into industries

(2) Investors divided into industries

(3) A single representative household

(4) An aggregate foreign purchaser of exports

(5) Government demands

(6) Changes in inventories

Each column details the purchases made by these agents, where each commodity type (C) can sourced domestically or through imports. The resulting output from use of these commodities is either consumed by households and governments domestically, exported, or used to bolster or reduce inventories. Some proportion of domestically produced goods is used to transfer commodities from their source industry to users - these are margins services (M) such as wholesale and retail trade, transport and private services. Taxes are payable on the purchase of commodities. In addition to these intermediate inputs, current production requires the use of three primary factors: labour (across occupations), fixed capital, and agricultural land. Production taxes include output taxes or subsidies that are identifiable to one user, while the 'other costs' category includes a range of other taxes on firms, such as regional taxes. Each cell in the absorption matrix describes the underlying data matrix, for instance, V2MAR is an array showing the level of margins services (M) on the flows of goods $(\mathrm{C})$, both domestically produced and imported (S), to investors (I).

[Insert Figure 1 here]

The MAKE matrix reports the value of output of each commodity by each industry, where each industry is capable of producing any commodity C. Tariffs on imports are applied at varying 
rates for commodities but not for users. In other words they are uniform across all users for a given commodity, with the tariff vector VOTAR reporting revenue raised from their application. Finally, the carbon emissions matrix reports carbon emissions by type of fuel, by source, and by user.

Figure 2 shows a schematic representation of the entire database in the form of a SAM. The SAM is an integrated framework that records all transactions in an economy in a given year at a level of aggregation that that reflects the underlying economic and social structure of the economy, in terms of interactions in the economy at both the microeconomic and macroeconomic levels. Specifically, the SAM represents net income distribution in a matrix, with rows representing receipts while column entries track expenditures in which each flow is both recorded as a receipt and an expense. The residual savings row allows the row sum for each account to equal the corresponding column sum.

The model uses Philippine dataset for the year 2010 which is the base year for calibration. The Philippine SAM shown in Figure 2 is based on a combination of data from the Input-Output table, National Income and Product accounts, the national household survey (the Family Income and Expenditure Survey) and the Labour Force Survey for the year 2010 (see Corong and Horridge, 2012, for details). The figure provides a contrast between the SAM and the inputoutput database shown in Figure 1. The first 8 rows of the SAM correspond to the input-output table database shown in Figure 1, while cells shaded in grey represent data drawn elsewhere or not found in the input-output table. Entries in the SAM are named according to the row and 
column in which they appear. For example, VHOUGOS represents the value of household income from gross operating surplus (or capital), while VGOVROW is the foreign aid received by the government. Capital income shares of agents are sourced from the national income accounts. In turn, each household's share in total capital income earned by all households in the economy is taken from the household survey.

\section{[Insert Figure 2 here]}

Finally, the model's underlying database and structure allows for the disaggregation of fuel type and use, and the resulting carbon emissions across the economy. Figure 3 shows some basic information from PHILGEM-E's carbon emissions matrix. In 2010 (base year), the Philippines emitted 74.5 metric tons (Mt) of $\mathrm{CO}_{2}$. The use of coal accounts for $37 \%$ of total carbon emissions while diesel, gasoline and natural gas account for $24 \%, 11 \%$ and $10 \%$ shares, respectively. In terms of emitting sectors, the main sources of emissions were electricity generation and transport due to their reliance on fossil fuels-together they account for $75 \%$ of total carbon emissions in the economy. Manufacturing follows with $16 \%$, while the combined share of agriculture and household is $8 \%$. Carbon emissions from petroleum refining contribute around $1 \%$.

[Insert Figure 3 here]

\section{Results}

The Philippines is a minor carbon emitter relative to other Asian countries (Figure 4) and not formally obliged to control its emissions as a member of Non-Annex 1 parties under the UNFCC (SEPA, 2013). However, its emissions have been on the rise and responding to the issue of climate change has become a part of the Philippines' national policy agenda. We use the 
PHILGEM-E model to examine the economy-wide impacts of three policy responses to climate change in the Philippines. Three policy simulations were run and their effects traced by decomposing the results into macro, sectoral and household effects overtime. To understand the effectiveness of a policy change, we focus on analysing the impact of a policy on the first year (2015) and last year (2020) of implementation. All simulations are carried out against a Baseline Case. It is important to note that all results are presented as cumulative percentage deviations relative to the economy's baseline. Presenting results in this way allows us to isolate the economic effects of an imposed climate policy.

\section{[Insert Figure 4 here]}

\subsection{The Baseline Case}

Using the initial database and exogenous information including a $5 \%$ yearly depreciation rate and a $6 \%$ GDP growth forecast, the dynamic model is solved to generate a plausible balanced growth path (baseline forecast) from 2010 to 2020. Assuming the Philippines continues with its current policy regime, total fossil-fuel related carbon emissions will increase from $74.5 \mathrm{MtCO}_{2} \mathrm{e}$ in 2010 to $122.4 \mathrm{MtCO}_{2} \mathrm{e}$ in 2020 (Figure 5). This 69\% growth is largely due to the significant increase in emissions coming from carbon-intensive fuels, particularly coal, diesel, gasoline and fuel oil. Figure 6 tracks the carbon emission trajectory of different types of fossil fuels overtime. It shows that emissions generated from coal, diesel oil and gasoline would rise by $22 \%, 6.8 \%$ and $6.3 \%$ respectively, while emissions from natural gas would increase by roughly $6 \%$. This is not surprising given that electricity generation in the Philippines is heavily reliant on fossil fuels and less on carbon-free and renewable generation technologies (Figure 7).

[Insert Figures 5, 6, and 7 here] 


\subsection{Effects of a carbon tax}

This simulation involves the imposition from 2015 to 2020, of a 200 peso tax per metric ton of carbon emission arising from fossil fuel use. This amount is equivalent to the current European market carbon price of \$US5. Implementing a carbon tax reduces total Philippine carbon emissions by $1.1 \%$ in the first year of implementation; and a $9.8 \%$ cumulative reduction by 2020. As shown in Table 2, much of the decrease is due to the reduction in coal-related carbon emissions (8.2\%). This is expected since coal bears the full burden of the carbon tax-i.e., being the most carbon-intensive fuel and the major source of energy in the Philippines. The combined cumulative emission reduction of diesel oil, gasoline and liquefied petroleum gas (LPG) is $2.3 \%$ by 2020 . Despite the carbon tax, carbon emissions from natural gas increase by $0.5 \%$ by 2020 . This is because the electricity industry substitutes away from coal towards natural gas-fired power generation, and alternative carbon-free generation technologies.

The gain for the environment comes at a cost in terms of contraction in the GDP as well as household income reduction. Real GDP growth falls by $0.1 \%$ and $0.6 \%$ by 2015 and 2020, respectively. Table 3 decomposes the contribution of each GDP component to total changes in GDP. It shows that the reduction in real GDP overtime is anchored on falling aggregate consumption, investment, and government expenditure. Aggregate consumption and investment each registers a $0.6 \%$ cumulative contraction by 2020 , while cumulative government expenditures fall by $0.1 \%$. Exports expand by $0.2 \%$, while lower imports help augment GDP growth by $0.4 \%$. Table 4 shows the movements in economy-wide price indices. Although the aggregate consumer price index (CPI) registers a cumulative fall of $0.1 \%$ by 2020 , 
it is not enough to boost aggregate real consumption which contracts by $0.6 \%$. Falling consumption is traceable to income-effects as all households experience a real income reduction of $1.2 \%$ by 2020 . As shown at the bottom of Table 4 , the carbon tax results in falling nominal factor returns which in turn reduces both nominal and real household income. Falling income combined with rising unemployment $(-0.6 \%$ by 2020$)$ then depresses household consumption.

In spite of higher energy prices brought about by the carbon tax, it is important to note that the GDP price deflator falls (Table 4). This arises mainly from industry output price effects, which confirms that lower price of value added (labour and capital) outweighs the impact of higher energy prices. In the wake of rising energy costs, firms reduce their output. As demand for primary factors are tied to output levels, firms reduce their employment, thereby resulting in falling economy-wide wages. In turn, lower output reduces profitability which drives down the return to capital. The lower price of capital then reduces production and demand for investment goods, thus explaining why aggregate investment registers a $0.6 \%$ cumulative reduction by 2020 .

The export price index falls (Table 4) in the wake of falling output prices and general price level. As a result, the terms of trade deteriorates while the real exchange rate depreciates $\quad(-0.1 \%$ and $0.3 \%$ in Table 4). Both these effects make Philippine exports relatively cheaper in the international market hence boosting cumulative exports (0.2\% in Table 5). Exports increase particularly for the export-intensive semi-conductor commodity which accounts for roughly 
$80 \%$ of total exports. This is the reason behind the output expansion of the semi-conductor industry (Table 5). The real exchange rate depreciation also reduces over-all demand for imports $(-0.2 \%$ by 2020$)$, as they are now relatively more expensive.

The carbon tax leads to an output contraction for most industries (Table 5). This is especially so for those producing carbon emitting fuels as demand for their products fall. The most affected industry is coal. Its output falls by $0.5 \%$ on the first year of carbon tax implementation and $9.7 \%$ by 2020 . Production level of the petroleum refining sector falls by $2.3 \%$ by 2020 as the economy reduces its consumption of carbon-emitting fuels. The "crude oil and natural gas extraction" industry also registers an output contraction of $1.7 \%$ by 2020 . Among non-energy producing industries, metal products have the highest cumulative output contraction (-2.6\% by 2020$)$. This is largely due to its reliance on carbon emitting production inputs, notably in cement manufacturing, which is an intensive user of coal.

The effect on the electricity industry is as expected. The carbon tax imposes its heaviest burden on coal-fired electricity generation, which experiences a cumulative output contraction of $22.6 \%$ by 2020 . The carbon tax also induces the electricity sector to substitute away from carbon-intensive coal towards less carbon-intensive energy like natural gas and oil, as well as carbon-free energy such as hydro-power, geothermal power and renewables. Indeed, outputs of electricity generated from hydro, geothermal and renewables show a cumulative increase of $20 \%, 14.5 \%$ and $14.8 \%$, respectively. As well, electricity generated from less carbon-intensive oil and natural gas increases by $7.9 \%$ and $3 \%$, respectively. It should be noted that, as shown in 
Figure 6, electricity generated from natural gas accounts for $28 \%$ while oil only accounts for $11.5 \%$. Hence, in absolute terms, the output increase in electricity generated from natural gas output is higher than that of oil.

The impacts of the carbon tax are likewise felt at the household level. Table 6 shows the effect on households, which are classified into urban and rural households. The pattern of effects is the same across households, although the magnitude differs. Nominal incomes of rural households fall less because they are mostly employed in agriculture which contracts less. Price reduction impacts more significantly on urban dwellers due to their higher reliance on manufactured goods for which commodity prices decrease more. Nevertheless, urban-based households experience a slightly higher reduction in cumulative real income by 2020 (-1.1 for rural vs. -1.2 for urban households).

\subsection{Effects of improvement in energy efficiency}

This simulation analyses the economy-wide effects from 2015 to 2020, of a 2\% across the board energy efficiency improvement in all non-energy sectors and a $2 \%$ over-all efficiency improvement in electricity generation. Table 2 shows that efficiency improvements contribute to an $8.5 \%$ reduction in total cumulative carbon emissions by 2020 . Similar to the carbon tax scenario, reduced emissions from coal burning contributes the most with $4.2 \%$ followed by diesel, fuel oil, natural gas and gasoline with a combined cumulative reduction of $4.3 \%$. Carbon emissions of LPG and other petroleum increase marginally, but their emissions are offset by the 
higher emission reduction from other more carbon-intensive fuels. Note that natural gas emissions fall under this scenario, while it increases in the carbon tax scenario.

Relative to the baseline, efficiency improvements expand real GDP by $0.3 \%$ in 2015 and produce an additional $1.9 \%$ cumulative growth by 2020 (Table 3). A decomposition of total changes in GDP growth reveals that both consumption and investment contribute the most, with $1.7 \%$ and $0.8 \%$ respectively. However falling exports and higher imports $(-0.7 \%$ and $-0.4 \%$, respectively) act to reduce the increase in real GDP growth.

The movements in economy-wide indices are shown in Table 4. The aggregate consumer price index (CPI) shows a cumulative increase of $0.7 \%$ by 2020 , while the investment price index increases slightly more by $0.8 \%$ by 2020 . Higher aggregate consumption can be traced to higher factor returns as wages, return to capital and land rentals increase (Table 4). This in turn results in a $0.5 \%$ increase in nominal household income by 2015 and a 3.1\% cumulative increase by 2020. Thus, despite a higher CPI, household real income registers a cumulative increase of $2.4 \%$ by 2020 . Higher real income coupled with rising employment ( $0.9 \%$ by 2020) augment aggregate household consumption.

A majority of industries experience output expansion in light of improvements in energy efficiency (Table 5). However, this is not the case for energy producing industries that see their output level contract-as energy efficiency improvements bring about lower demand for their 
outputs. The biggest output gain is from the electricity sector with output growth ranging between $0.2 \%$ in oil-fired power generation and 3.3\% in renewable-power generation by 2020 .

The GDP price deflator registers a cumulative 1.1\% increase by 2020 (Table 4) due to higher cost of production emanating from higher factor prices. As explained earlier, demand for primary factors is tied to output levels. Higher output results in higher demand for labour, which then triggers an increase in wages. Moreover, higher output increases profitability of industries, thereby forcing rental rates (capital and land) to go up. This profitability then increases production and demand for investment goods, in turn producing an $0.8 \%$ cumulative increase in aggregate investment by 2020.

The export price index increase (Table 4) owing to higher cost of local production. Higher export prices results in an improvement in terms of trade $(0.4 \%$ in Table 4$)$ and a real exchange rate appreciation (-1.1 in Table 4). Both these effects make exports relatively more expensive abroad, leading to $0.7 \%$ reduction in cumulative exports by 2020 (Table 3). The real exchange rate appreciation also makes imported products relatively cheaper leading to a $0.2 \%$ cumulative increase in imports by 2020.

Households are better off as a result of efficiency improvements. Indeed, they benefit directly from higher returns to primary factors. As shown in Table 6, all households experience a $2.4 \%$ cumulative increase in real income by 2020 -as a rise in the consumer price index of $0.7 \%$ is outweighed by a higher increase in nominal income of $3.1 \%$. 


\subsection{Effects of changes in electricity generation mix}

The final policy simulation examines the combined effect of efficiency improvements (as performed in the previous simulation) and a policy prescribing an alternative electricity generation mix. From 2015 to 2020, a shift from coal-based to renewable-based electricity sourcing is imposed. A majority of results are similar to the energy efficiency simulation with only a few marked differences. Table 2 shows that efficiency improvements combined with changing the electricity generation mix results in an $11 \%$ reduction in total cumulative carbon emissions by $2020-2.5$ percentage points higher relative to efficiency improvements alone. This difference is due to the additional emission reduction contribution of coal which falls by $7.7 \%$ in this scenario compared to $4.2 \%$ in the previous scenario.

The output effects of each electricity generation fuel source are shown in Table 5. Owing to shift in electricity generation away from coal, the output of coal-fired power plants falls by $11.8 \%$ while the output of electricity generated from renewables increases by $18.6 \%$ by 2020 . Similarly, the output of natural gas increases by $7.7 \%$ owing to lower natural gas prices. The changes in output of other electricity generation technologies are similar to that of the previous scenario. 


\section{Discussion}

This paper outlines the use of the PHILGEM-E CGE model to examine the likely impacts on the economy of the Philippines from the introduction of various mitigation strategies, modelled in three simulations.

In Simulation 1, where a carbon tax is imposed, this action curbs emissions by $9.8 \%$ compared to the baseline projection by 2020 , including a reduction in coal emissions by $8.2 \%$. GDP is $0.6 \%$ lower than baseline in 2020 , led by identical falls in consumption and investment. Income effects for households are similar across broad regional groupings - a $1.16 \%$ decline for rural households and a $1.22 \%$ decline for urban households.

Simulation 2 analyses the economy-wide effects from 2015 to 2020, of a $2 \%$ across the board energy efficiency improvement in all non-energy industries, and a $2 \%$ over-all efficiency improvement in all electricity generation types. In this simulation, emissions fall by $8.5 \%$ compared to the baseline projection by 2020 . The decline is spread out amongst fuel types, with coal seeing a decline of only $4.2 \%$. GDP is higher than the baseline at around $1.9 \%$ compared to the projected 2020 level. Negative impacts on both exports and imports offset one another to some extent, with consumption and investment showing increases. Unlike the carbon tax simulation, income effects for households are similar across broad regional groupings - a $2.36 \%$ increase for rural households and a $2.35 \%$ increase for urban households. 
Simulation 3 examines the effect of energy efficiency combined with an alternative electricity generation mix policy. From 2015 to 2020, a 10\% shift from coal-based to renewable-based electricity sourcing is imposed. In this simulation, a fall in emissions of $11.0 \%$ compared to the baseline projection by 2020 represent the most marked decline among all three simulations. The decline is spread over all fuel types, although to a lesser extent than under Simulation 2. Coal sees a decline of only $7.7 \%$. GDP is higher than the baseline at around $1.9 \%$ compared to the projected 2020 level. This is a similar result to Simulation 2, with negative impacts on both exports and imports offsetting one another to some extent, while consumption and investment show increases. Also, income effects for households are similar across broad regional groupings - a $2.36 \%$ increase for rural households and a $2.37 \%$ increase for urban households.

\section{Conclusion}

Various policy strategies on climate change mitigation have mixed results for the Philippines, particularly in terms of their impact on the country's external account. This study shows the results from the simulation of three climate change policies using the PHILGEM-E model. They indicate that a policy response which encourages efficiency measures and a change in the mix of fuels used in electricity generation, has the lowest medium term impact on the economy (to 2020 ) in comparison with the introduction of a carbon tax. 


\section{References}

Adams, P., Mai Y., 2002, MMRF-Green projections of Greenhouse Gas Emissions for the Stationary Energy Sector. Centre of Policy Studies, Monash University, Melbourne.

Adkins, L., Garbaccio R., 2002, The Effects of the Proposed FTAA on Global Carbon Emissions: A General Equilibrium Analysis. National Center for Environmental Economics, U.S. Environmental Protection Agency, Washington DC.

Asian Development Bank (ADB), 2009, The Economics of Climate Change in Southeast Asia: A Regional Review. Asian Development Bank, Manila.

Allen Consulting Group, 2006, Deep Cuts in Greenhouse Gas Emissions: Economic, Social and Environmental Impacts for Australia. Report to the Business Roundtable of Climate Change, Allen Consulting Group, Sydney, Australia.

Babiker, M., 2005, Climate change policy, market structure, and carbon leakage. Journal of International Economics. 65, $421-445$.

Bandara, J. S. and Cai, Y., 2014, The impact of climate change on food crop productivity, food prices and food security in South Asia. Economic Analysis and Policy 44(4), 451-465.

Baranzini, A., Goldemberg, J. and Speck, S., 2000, A future for carbon taxes, Ecological Economics, Vol. 32, pp. 395-412.

Beghin, J., Bowland, B., Dessus, S., Roland-Holst, D., van der Mensbrugghe, D., 1999, Trade Integration, Environmental Degradation, and Public Health in Chile: Assessing Linkages. Working Paper 99-WP 211, Center for Agricultural and Rural Development, lowa State University, lowa.

Bohringer, C., 2000, Cooling down hot air: a global CGE analysis of post-Kyoto carbon abatement strategies. Energy Policy 28, 779-789

Bollen, J., Manders, T. and Timmer, H., 2000. Decomposing Carbon Leakage: An Analysis of the Kyoto Protocol. Third Annual Conference on Global Economic Analysis, Melbourne, Australia, 27-30 June.

Boyce, J., Riddle, M. and Brenner, M., 2005, A Chinese Sky Trust? Distributional Impacts of Carbon charges and Revenue Recycling in China, Working Papers Political Economy Research Institute, University of Massachusetts at Amherst.

Brendemoen, A. and Vannemo, H., 1994, A climate treaty and the Norwegian economy. Energy Journal 15(1), 77-94.

Breuss, F., Steininger, K., 1998, Biomass energy use to reduce climate change: A general equilibrium analysis for Austria. Journal of Policy Modeling 20 (4), 513 -535. 
Cabalu, H., and Rodriguez, U., 2007, Trade-offs in trade liberalization: evidence from the 2005 Philippine tariff changes. Journal of Economic Integration. 22 (3), 637-663.

Calzadilla, A., Rehdanz, K., and Tol, R. S. J., 2011, Trade Liberalisation and Climate Change: A CGE Analysis of the Impacts on Global Agriculture. Paper No. WP381, Economic and Social Research Institute (ESRI), UK.

Corong E., 2007, Economic and Poverty Impacts of a Voluntary Carbon Reduction for a Small Liberalized Developing Economy: The Case of the Philippines. Nota Di Lavoro 9.2007

Corong, E., 2008, Tariff reductions, carbon emissions and poverty: an economywide assessment of the Philippines. ASEAN Economic Bulletin 25(1), 20 -31.

Corong, E. and Horridge, M., 2012, PHILGEM: A SAM-based Computable General Equilibrium Model of the Philippines. Centre of Policy Studies/IMPACT Centre Working Papers G-227, Victoria University.

Cororaton, C. and Cockburn, J., 2007, Trade reform and poverty - lessons from the Philippines: a CGE-microsimulation analysis. Journal of Policy Modeling 29, 141 - 163

Department of Environment and Natural Resources (DENR), 1999, The Philippines' Initial National Communication on Climate Change Department of Environment and Natural Resources, Manila.

Dufournaud, C., Jerrett, M., Rodriguez, U., Quinn, J., and Inocencio, A., 2003, The net cost of banning commercial foresting: An AGE analysis for the Philippines. Environment and Planning 35(April), $745-758$.

Fujimori S., Hasegawa T., Masui T. and Takahashi K., 2014a, Land use representation in a global CGE model for long-term simulation: CET vs. logit functions. Food Security, 6 (5), 685-699

Fujimori S., Kainuma M., Masui T., Hasegawa T., Dai H. 2014b, The effectiveness of energy service demand reduction: A scenario analysis of global climate change mitigation. Energy Policy 75, 379-391.

Garbaccio, R., Ho, M., Jorgenson, D., 1998, Controlling Carbon Emissions in China. Kennedy School of Government, Harvard University, Cambridge, Massachussetts.

Horridge, M., Parmenter, B. and Pearson, K., 2000, ORANI-G: A general equilibrium model of the Australian economy. Centre of Policy Studies, Monash University, Melbourne.

Inocencio, A., Dufournaud, C. and Rodriguez, U., 2001, Impact of Tax Changes on Environmental Emissions: An Applied General Equilibrium Approach for the Philippines. Research Paper No. 7, IMAPE Project, Policy and Development Foundation, Makati, Philippines.

IPCC, 2007. Fourth Assessment Report. Intergovernmental Panel on Climate Change, Cambridge, UK. 
Jaffe, A., Peterson, P., Portney, P. and Stavins, R., 1995, Environmental Regulation and the Competitiveness of U.S. Manufacturing: What Does the Evidence Tell Us?, Journal of Economic Literature, American Economic Association, vol. 33(1), pages 132-163, March.

Kang, S. and Kim, J., 2004, A Quantitative Analysis of the Environmental Impact Induced by Free Trade between Korea and Japan. Paper presented at the 7th Annual Conference on Global Analysis, Trade, Poverty and the Environment, Washington DC.

Klepper, G. and Peterson, S., 2006, Emissions trading, CDM, Jl, and more: the climate strategy of the EU. Energy Journal 27(2), 1- 26

McDougall, R., 1993, Energy Taxes and Greenhouse Gas Emissions in Australia, Centre of Policy Studies/IMPACT Centre Working Papers G-104, Victoria University.

Nurdianto, D. and Resosudarmo, B., 2014, The Inter-regional System of Analysis for ASEAN: A Manual, Working Paper in Economics and Development Studies, No. 201411, University of Padjadjaran, Indonesia.

OECD, 1994, The Distributive Effects of Economic Instruments for Environmental Policy, OECD, Paris.

OECD, 1996, Implementation Strategies for Environmental Taxes, OECD, Paris.

Philippines Government, 2010, National Framework Strategy on Climate Change, Manila, Philippines.

Pinto, L. and Harrison, G. 2003, Multilateral negotiations over climate change policy. Journal of Policy Modelling 25, 911- 930

Rana, A., 2003, Evaluation of renewable energy scenario in India for economic and $\mathrm{CO}_{2}$ mitigation effects. Review of Urban and Regional Studies 15(1), 45-54.

Rincon and Virtucio, 2008, Climate Change in the Philippines: A Contribution to the Country Environmental Analysis

Rodriguez, U., 2009, An economy-wide analysis of the impacts of a free trade area of the AsiaPacific on the Philippine economy, Journal of Global Business and Trade 5(1), 43-55.

Rodriguez, U., Garcia, Y., Tan, R. and Garcia, A., 2007, Can trade policies soften the economic impacts of an avian influenza outbreak? Simulations from a CGE model of the Philippines. Asian Journal of Agriculture and Development 4(2), 41-50.

Telli, C., Voyvoda, E., and Yeldan, E., 2008, Economics of environmental policy in Turkey: a general equilibrium investigation of the economic evaluation of sectoral emission reduction policies for climate change. Journal of Policy Modelling 30, 321-340

Glomsrod, S., Vannemo, H. and Johnsen, T., 1992, 'Stabilisation of CO2: a computable general equilibrium assessment, The Scandinavian Journal of Economics, Vol. 94, No. 1, pp. 53-69. 
Govinda, T., and Mevel, S., 2013, Biofuels and Climate Change Mitigation: A CGE Analysis Incorporating Land-Use Change. Environmental \& Resource Economics, European Association of Environmental and Resource Economists 55(1), 1-19.

Jaafar, A. H., Al-Amin, A. Q. and Siwar, C., 2008, "A CGE Analysis of the Economic Impact of Output-Specific Carbon Tax on the Malaysian Economy," MPRA Paper 10210, University Library of Munich, Germany.

Jensen, J., O'Toole, R. and Matthews, A., 2003, "Controlling greenhouse gas emissions from the agricultural sector in Ireland: a CGE modelling approach," Paper presented at the 6th Annual Conference on Global Economic Analysis The Hague, June 2003.

Pal, B.D., Ojha, V.P., Pohit, S. and Roy, J., 2015, Impact of economic growth on greenhouse gas (GHG) emissions-social accounting matrix (SAM) multiplier analysis in GHG emissions and economic growth: A Computable General Equilibrium Model Based Analysis for India, Springer India, pp. 43-60.

Palatnik, R. and Shechter, M., 2008, Can Climate Change Mitigation Policy Benefit the Israeli Economy? A Computable General Equilibrium Analysis, FEEM Working Paper 2.2008.

Poterba, J. M., 1991, Tax policy to combat global warming: on designing a carbon tax in R. Dornbusch and J. M. Poterba (eds), Global Warming Economic Policy Responses, MIT Press, Cambridge, Massachussetts, pp. 71-98.

Telli, C., E. Voyvoda, and Yeldan, E., 2008, Economics of environmental policy in Turkey: A general equilibrium investigation of the economic evaluation of sectoral emission reduction policies for climate change, Journal of Policy Modelling, 30, 321-340.

Timilsina, G. and Mevel, S., 2013, Biofuels and Climate Change Mitigation: A CGE Analysis Incorporating Land-Use Change, Environmental and Resource Economics, Volume 55, Issue 1, pp 1-19.

United Nations Framework Convention on Climate Change (UNFCCC), 2007, Climate Change: Impacts, Vulnerabilities, and Adaptation in Developing Countries., Bonn, Germany.

van Heerden, J., Gerlagh, R., Blignaut, J., Horridge, M., Hess, S., Mabagu, R. and Mabagu, M., 2006, Searching for triple dividends in South Africa: fighting $\mathrm{CO}_{2}$ pollution and poverty while promoting growth. Energy Journal 27(2), 113-141.

Whalley, J. and Wigle, R., 1991, Cutting $\mathrm{CO}_{2}$ emissions: the effects of alternative policy approaches. Energy Journal 12(1), 109-124.

Wing, I., 2009, Computable general equilibrium models for the analysis of energy and climate policies. In: Hunt, L., Evans, J.,(Eds.), International Handbook of the Economics of Energy. Edward Elgar Publishing, pp. 332-366. 
World Bank, 2010a, World Development Report 2010: Development and Climate Change. World Bank, Washington DC.

World Bank, 2010b. A Strategic Approach to Climate Change in the Philippines. Washington, DC.

Yusuf, A., Komarulzaman, A., Hermawan, W., Hartono, D., Sjahrir, K., 2010. Scenarios for Climate Change Mitigation from the Energy Sector in Indonesia: The Role of Fiscal Instruments. Working Paper in Economics and Development Studies No. 201005. Center for Economics and Development Studies, Department of Economics, Padjadjaran University.

Yusuf, A. and Resosudarmo, B., 2015. On the distributional impact of a carbon tax in developing countries: the case of Indonesia. Environmental Economics and Policy Studies 17 (1), 131156. 
Table 1: Commodity and industry classification

\begin{tabular}{|c|c|c|c|c|}
\hline & Commodity Description & Elements of Set COM & & Industry Description \\
\hline 1 & Paddy rice & Paddy & 1 & Paddy rice \\
\hline 2 & Corn & Corn & 2 & Corn \\
\hline 3 & Fruits and vegetables & FruitsVege & 3 & Fruits and vegetables \\
\hline 4 & Other crops & OtherCrops & 4 & Other crops \\
\hline 5 & Livestock and poultry & LvstkPoultry & 5 & Livestock and poultry \\
\hline 6 & Other agriculture & OtherAgric & 6 & Other agriculture \\
\hline 7 & Mining & Mining & 7 & Mining \\
\hline 8 & Coal & Coal (Carbon) & 8 & Coal \\
\hline 9 & Crude oil & Crude (Carbon) & 9 & Crude oil and natural gas \\
\hline 10 & Natural gas & NatGas (Carbon) & & \\
\hline 11 & Processed food & ProcFood & 10 & Processed food \\
\hline 12 & Rice, corn, sugar milling & Rice & 11 & Rice, corn, sugar milling \\
\hline 13 & Tobacco and alcohol & TobacAlchl & 12 & Tobacco and alcohol \\
\hline 14 & Textile, garments and footwear & TextGarmFoot & 13 & Textile, garments and footwear \\
\hline 15 & Other manufacturing & OtherManuf & 14 & Other manufacturing \\
\hline 16 & Chemicals & Chemicals & 15 & Chemicals \\
\hline 17 & Gasoline & Gasoline (Carbon) & 16 & Petroleum refinery \\
\hline 18 & Diesel oil & DieselOil (Carbon) & & \\
\hline 19 & Fuel oil & FuelOil (Carbon) & & \\
\hline 20 & Liquefied petroleum gas & LPG (Carbon) & & \\
\hline 21 & Other petroleum products & OthPetrol (Carbon) & & \\
\hline 22 & Metal products & Metals & 17 & Metal products \\
\hline 23 & Machineries & Machines & 18 & Machineries \\
\hline 24 & Electric appliances & ElecRelAppli & 19 & Electric appliances \\
\hline 25 & Semi-conductors & Semicon & 20 & Semi-conductors \\
\hline 26 & Electricity-oil & ElecOil & 21 & Electricity-oil \\
\hline 27 & Electricity-hydro & ElecHydro & 22 & Electricity-hydro \\
\hline 28 & Electricity-geothermal & ElecGeoth & 23 & Electricity-geothermal \\
\hline 29 & Electricity-coal & ElecCoal & 24 & Electricity-coal \\
\hline 30 & Electricity-Natural gas & ElecNatGas & 25 & Electricity-Natural gas \\
\hline 31 & Electricity-renewables & ElecRenew & 26 & Electricity-renewables \\
\hline 32 & Electricity distribution & ElecDist & 27 & Electricity distribution \\
\hline 33 & Utilities & Utilities & 28 & Utilities \\
\hline 34 & Retail \& wholesale trade & Trade (Margin) & 29 & Retail \& wholesale trade \\
\hline 35 & Transport & Transport (Margin) & 30 & Transport \\
\hline 36 & Communication & Communicate & 31 & Communication \\
\hline 37 & Construction & Construction & 32 & Construction \\
\hline 38 & Ownership of dwellings & Dwellings & 33 & Ownership of dwellings \\
\hline 39 & Public services & PublicSrvcs & 34 & Public services \\
\hline 40 & Private services & PrivateSrvcs (Margin) & 35 & Private services \\
\hline
\end{tabular}


Figure 1: Schematic representation of the input-output table

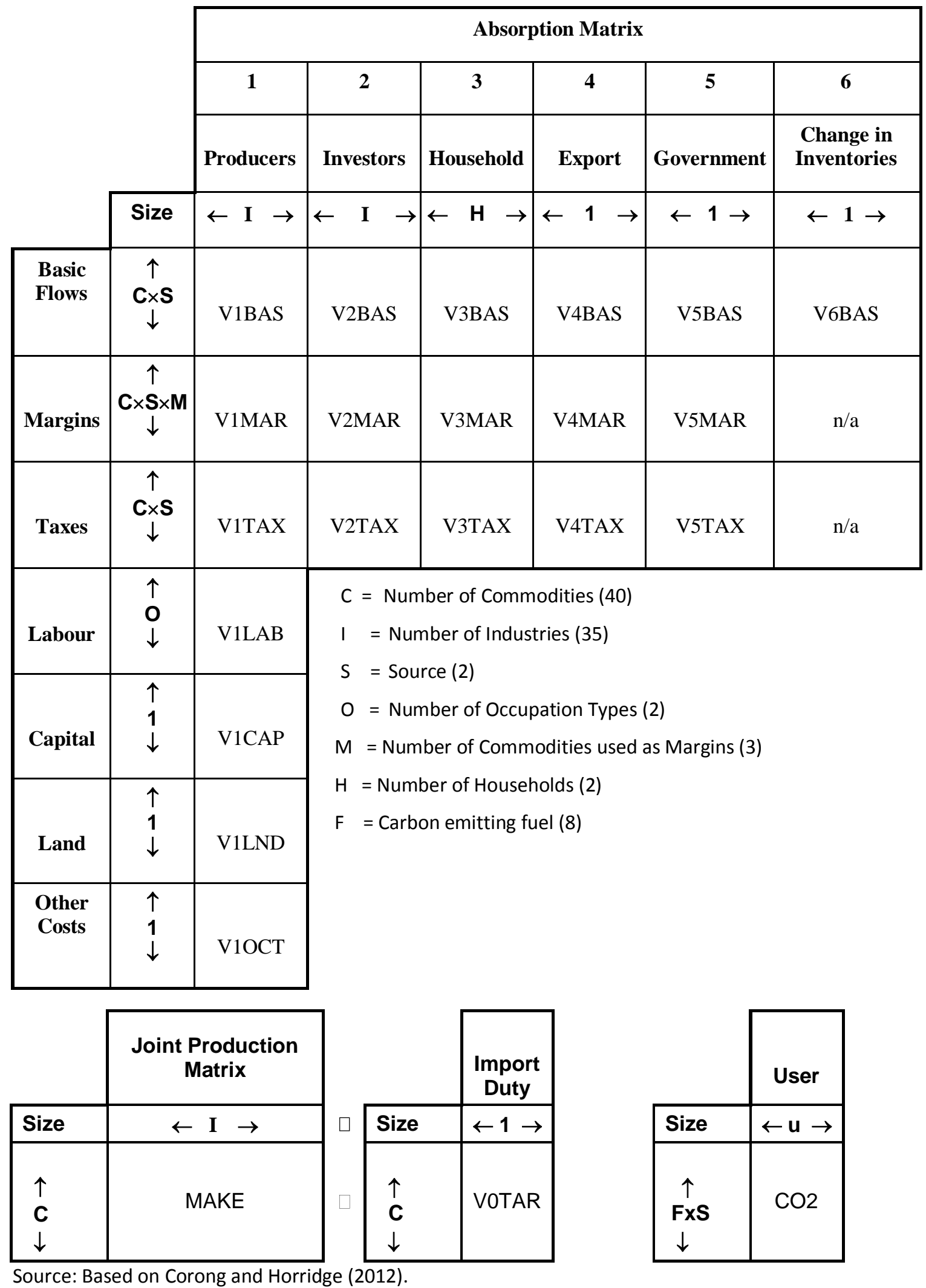


Figure 2: Schematic representation of an aggregate social accounting matrix

\begin{tabular}{|c|c|c|c|c|c|c|c|c|c|}
\hline & & $\begin{array}{c}1 \\
\text { Industries }\end{array}$ & $\begin{array}{c}2 \\
\text { Domestic } \\
\text { Commodities } \\
\end{array}$ & $\begin{array}{c}3 \\
\text { Imported } \\
\text { commodities } \\
\end{array}$ & $\begin{array}{c}4 \\
\text { Labour }\end{array}$ & $\begin{array}{c}5 \\
\text { Capital }\end{array}$ & $\begin{array}{c}6 \\
\text { Production Tax }\end{array}$ & $\begin{array}{c}7 \\
\text { Commodity Tax }\end{array}$ & $\begin{array}{c}8 \\
\text { Tariff }\end{array}$ \\
\hline & & $\leftarrow I \rightarrow$ & $\leftarrow \mathbf{C} \rightarrow$ & $\leftarrow \mathbf{C} \rightarrow$ & $\leftarrow 0 \rightarrow$ & $\leftarrow \mathbf{K} \rightarrow$ & $\leftarrow 1 \rightarrow$ & $\leftarrow \mathbf{C} \rightarrow$ & $\leftarrow$ C $\rightarrow$ \\
\hline $\begin{array}{c}1 \\
\text { Industries }\end{array}$ & $\begin{array}{l}\uparrow \\
\mathbf{I} \\
\downarrow\end{array}$ & & MAKE & & & & & & \\
\hline $\begin{array}{c}2 \\
\text { Domestic } \\
\text { Commodities }\end{array}$ & $\begin{array}{l}\uparrow \\
\mathbf{C} \\
\downarrow\end{array}$ & $\begin{array}{c}\text { V1BAS("dom") } \\
+ \\
\text { V1MAR(“'dom") }\end{array}$ & & & & & & & \\
\hline $\begin{array}{c}3 \\
\text { Imported } \\
\text { commodities } \\
\end{array}$ & $\begin{array}{l}\uparrow \\
\mathbf{C} \\
\downarrow\end{array}$ & $\begin{array}{c}\text { V1BAS(“imp") } \\
+ \\
\text { V1MAR("imp") } \\
\end{array}$ & & & & & & & \\
\hline $\begin{array}{c}4 \\
\text { Labour }\end{array}$ & $\begin{array}{l}\uparrow \\
0 \\
\downarrow\end{array}$ & V1LAB & & & & & & & \\
\hline $\begin{array}{c}5 \\
\text { Capital }\end{array}$ & $\begin{array}{l}\uparrow \\
\mathbf{K} \\
\downarrow\end{array}$ & $\begin{array}{l}\text { V1CAP + } \\
\text { V1LND }\end{array}$ & & & & & & & \\
\hline $\begin{array}{c}6 \\
\text { Production Tax }\end{array}$ & $\begin{array}{l}\uparrow \\
1 \\
\downarrow\end{array}$ & $\begin{array}{l}\text { V1PTX + } \\
\text { V1OCT }\end{array}$ & & & & & & & \\
\hline $\begin{array}{c}7 \\
\text { Commodity } \\
\text { Tax } \\
\end{array}$ & $\begin{array}{l}\uparrow \\
\text { C } \\
\downarrow\end{array}$ & V1TAX & & & & & & & \\
\hline $\begin{array}{c}8 \\
\text { Tariff }\end{array}$ & $\begin{array}{l}\uparrow \\
\mathbf{1} \\
\downarrow\end{array}$ & & & VOTAR & & & & & \\
\hline $\begin{array}{c}9 \\
\text { Direct Tax }\end{array}$ & $\begin{array}{l}\uparrow \\
1 \\
\downarrow\end{array}$ & & & & & & & & \\
\hline $\begin{array}{c}10 \\
\text { Households }\end{array}$ & $\begin{array}{l}\uparrow \\
\mathbf{H} \\
\downarrow\end{array}$ & & & & V1LAB & VHOUGOS & & & \\
\hline $\begin{array}{c}11 \\
\text { Enterprises }\end{array}$ & $\begin{array}{l}\uparrow \\
1 \\
\downarrow\end{array}$ & & & & & VENTGOS & & & \\
\hline $\begin{array}{c}12 \\
\text { Government }\end{array}$ & $\begin{array}{l}\uparrow \\
1 \\
\downarrow\end{array}$ & & & & & VGOVGOS & $\begin{array}{c}\text { V1PTX } \\
+ \\
\text { V1OCT }\end{array}$ & VOTAX & VOTAR \\
\hline $\begin{array}{c}13 \\
\text { Government } \\
\text { Savings }\end{array}$ & $\begin{array}{l}\uparrow \\
1 \\
\downarrow\end{array}$ & & & & & & & & \\
\hline $\begin{array}{c}14 \\
\text { Private } \\
\text { Savings } \\
\end{array}$ & $\begin{array}{l}\uparrow \\
1 \\
\downarrow\end{array}$ & & & & & & & & \\
\hline $\begin{array}{c}15 \\
\text { Stocks }\end{array}$ & $\begin{array}{l}\uparrow \\
1 \\
\downarrow\end{array}$ & & & & & & & & \\
\hline $\begin{array}{c}16 \\
\text { Rest of the } \\
\text { World }\end{array}$ & $\begin{array}{l}\uparrow \\
1 \\
\downarrow\end{array}$ & & & VOCIF & & & & & \\
\hline $\begin{array}{c}17 \\
\text { Total }\end{array}$ & $\begin{array}{l}\uparrow \\
1 \\
\downarrow\end{array}$ & Output & $\begin{array}{c}\text { Supply of } \\
\text { domestic } \\
\text { Commodities }\end{array}$ & $\begin{array}{c}\text { Supply of } \\
\text { Imported } \\
\text { Commodities }\end{array}$ & Wage Costs & Cost of Capital & Production Tax & Commodity Tax & Tariff \\
\hline
\end{tabular}

Legend: I - No. of Industries; C - No. of Commodities; O - No. of Occupation Types; K - No. of Types of Capital; H - No. of Household Types; 1 - Single vector

Note: Shaded cells represent additional data from the SAM (i.e., not found in the IO table). 
Figure 2 (cont'd): Schematic representation of an aggregate social accounting matrix

\begin{tabular}{|c|c|c|c|c|c|c|c|c|}
\hline$\stackrel{9}{\text { Direct Tax }}$ & $\begin{array}{c}10 \\
\text { Households }\end{array}$ & $\begin{array}{c}11 \\
\text { Enterprises }\end{array}$ & $\begin{array}{c}12 \\
\text { Government }\end{array}$ & $\begin{array}{c}13 \\
\text { Government } \\
\text { Investment }\end{array}$ & $\begin{array}{c}14 \\
\text { Private } \\
\text { Investment }\end{array}$ & $\begin{array}{c}15 \\
\text { Stocks }\end{array}$ & $\begin{array}{c}16 \\
\text { Rest of the } \\
\text { World }\end{array}$ & $\begin{array}{c}17 \\
\text { Total }\end{array}$ \\
\hline$\leftarrow 1 \rightarrow$ & $\leftarrow \mathbf{H} \rightarrow$ & $\leftarrow 1 \rightarrow$ & $\leftarrow 1 \rightarrow$ & $\leftarrow 1 \rightarrow$ & $\leftarrow 1 \rightarrow$ & $\leftarrow 1 \rightarrow$ & $\leftarrow 1 \rightarrow$ & $\leftarrow 1 \rightarrow$ \\
\hline & & & & & & & & Sales \\
\hline & $\begin{array}{l}\text { V3BAS(“dom")+ } \\
\text { V3MAR(“dom") }\end{array}$ & & $\begin{array}{l}\text { V5BAS(“dom")+ } \\
\text { V5MAR(“dom") }\end{array}$ & $\begin{array}{l}\text { V2BAS_I(“dom")+ } \\
\text { V2MAR_I(“dom") }\end{array}$ & $\begin{array}{l}\text { V2BAS_I(“dom”)+ } \\
\text { V2MAR_I(“dom") }\end{array}$ & V6BAS("dom“) & $\begin{array}{l}\text { V4BAS(“dom")+ } \\
\text { V4MAR(“dom") }\end{array}$ & $\begin{array}{l}\text { Demand for } \\
\text { Domestic } \\
\text { Commodities }\end{array}$ \\
\hline & $\begin{array}{l}\text { V3BAS("imp")+ } \\
\text { V3MAR(“imp") }\end{array}$ & & $\begin{array}{l}\text { V5BAS(“imp") + } \\
\text { V5MAR("imp") }\end{array}$ & $\begin{array}{l}\text { V2BAS_I(“imp”) + } \\
\text { V2MAR_I(“imp”) }\end{array}$ & $\begin{array}{l}\text { V2BAS_I(“imp") + } \\
\text { V2MAR_I(“imp") }\end{array}$ & V6BAS(“imp") & & $\begin{array}{l}\text { Demand for } \\
\text { Imported } \\
\text { Commodities }\end{array}$ \\
\hline & & & & & & & & $\begin{array}{l}\text { Wage } \\
\text { Income }\end{array}$ \\
\hline & & & & & & & & $\begin{array}{l}\text { Capital } \\
\text { Income }\end{array}$ \\
\hline & & & & & & & & $\begin{array}{l}\text { Production } \\
\text { Tax }\end{array}$ \\
\hline & V3TAX & & V5TAX & V2TAX & V2TAX & & V4TAX & Commodity Tax \\
\hline & & & & & & & & Tariff \\
\hline & VTAXHOU & VTAXENT & & & & & & $\begin{array}{l}\text { Income } \\
\text { Tax }\end{array}$ \\
\hline & VHOUHOU & VHOUENT & VHOUGOV & & & & VHOUROW & $\begin{array}{l}\text { Household } \\
\text { Income }\end{array}$ \\
\hline & VENTHOU & & VENTGOV & & & & VENTROW & $\begin{array}{l}\text { Enterprises' } \\
\text { Income }\end{array}$ \\
\hline \multirow[t]{5}{*}{$\begin{array}{c}\text { VTAXHOU } \\
+ \\
\text { VTAXENT } \\
\end{array}$} & VGOVHOU & VGOVENT & & & & & VGOWROW & $\begin{array}{l}\text { Government } \\
\text { Income }\end{array}$ \\
\hline & & & VGOVINV & & & & & $\begin{array}{l}\text { Government } \\
\text { Investment }\end{array}$ \\
\hline & VSAVHOU & VSAVENT & VSAVGOV & & & & VSAVROW & Savings \\
\hline & & & & & VSTKINV & & & Stocks \\
\hline & & VROWENT & VROWGOV & & & & & $\begin{array}{l}\text { Foreign Exchang } \\
\text { Receipts }\end{array}$ \\
\hline Income Tax & $\begin{array}{l}\text { Household } \\
\text { Expenditures }\end{array}$ & $\begin{array}{l}\text { Enterprises' } \\
\text { Expenditure }\end{array}$ & $\begin{array}{l}\text { Government } \\
\text { Expenditure }\end{array}$ & $\begin{array}{l}\text { Government } \\
\text { Investment }\end{array}$ & Private Investment & Stocks & $\begin{array}{c}\text { Foreign } \\
\text { Exchange } \\
\text { Receipts }\end{array}$ & \\
\hline
\end{tabular}

Legend: I - No. of Industries; C - No. of Commodities; O - No. of Occupation Types; K - No. of Types of Capital; $\mathrm{H}$ - No. of Household Types; 1 - Single vector

Note: Shaded cells represent additional data from the SAM (i.e., not found in the IO table). 
Figure 3: Carbon emissions by fuel type and user (percentage share), 2010

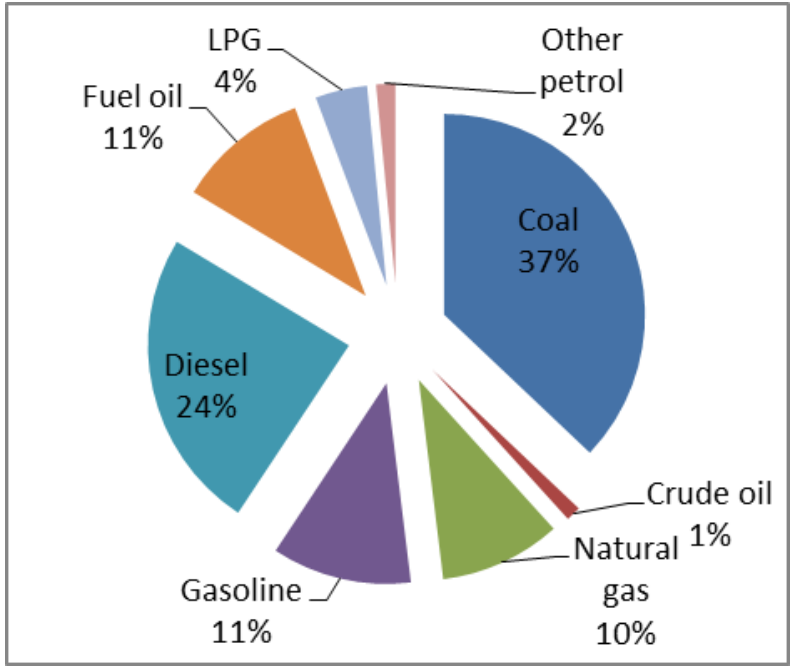

Source: Model database

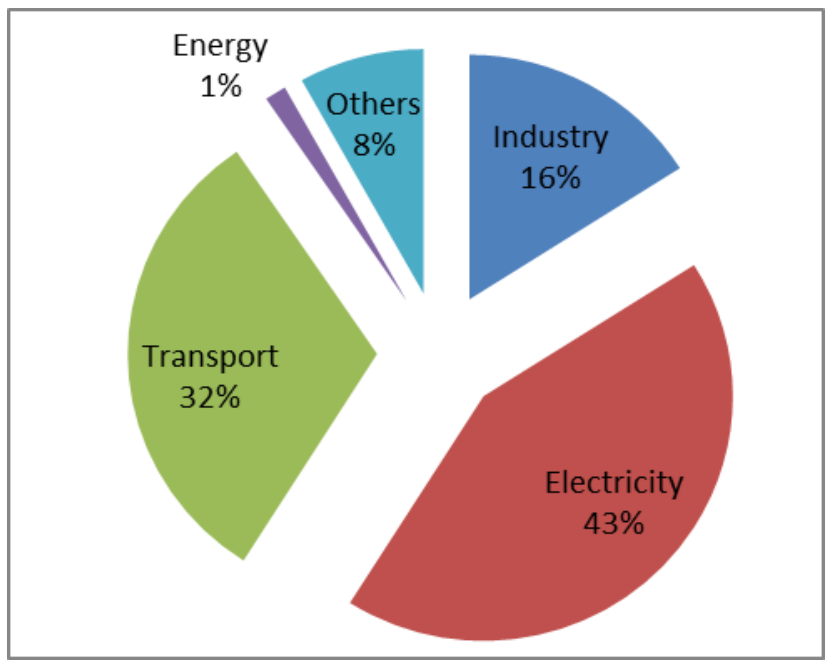

Source: Model database 
Figure 4: $\mathrm{CO}_{2}$ emissions per capita in selected Asian countries (in metric ton, 1980-2010)

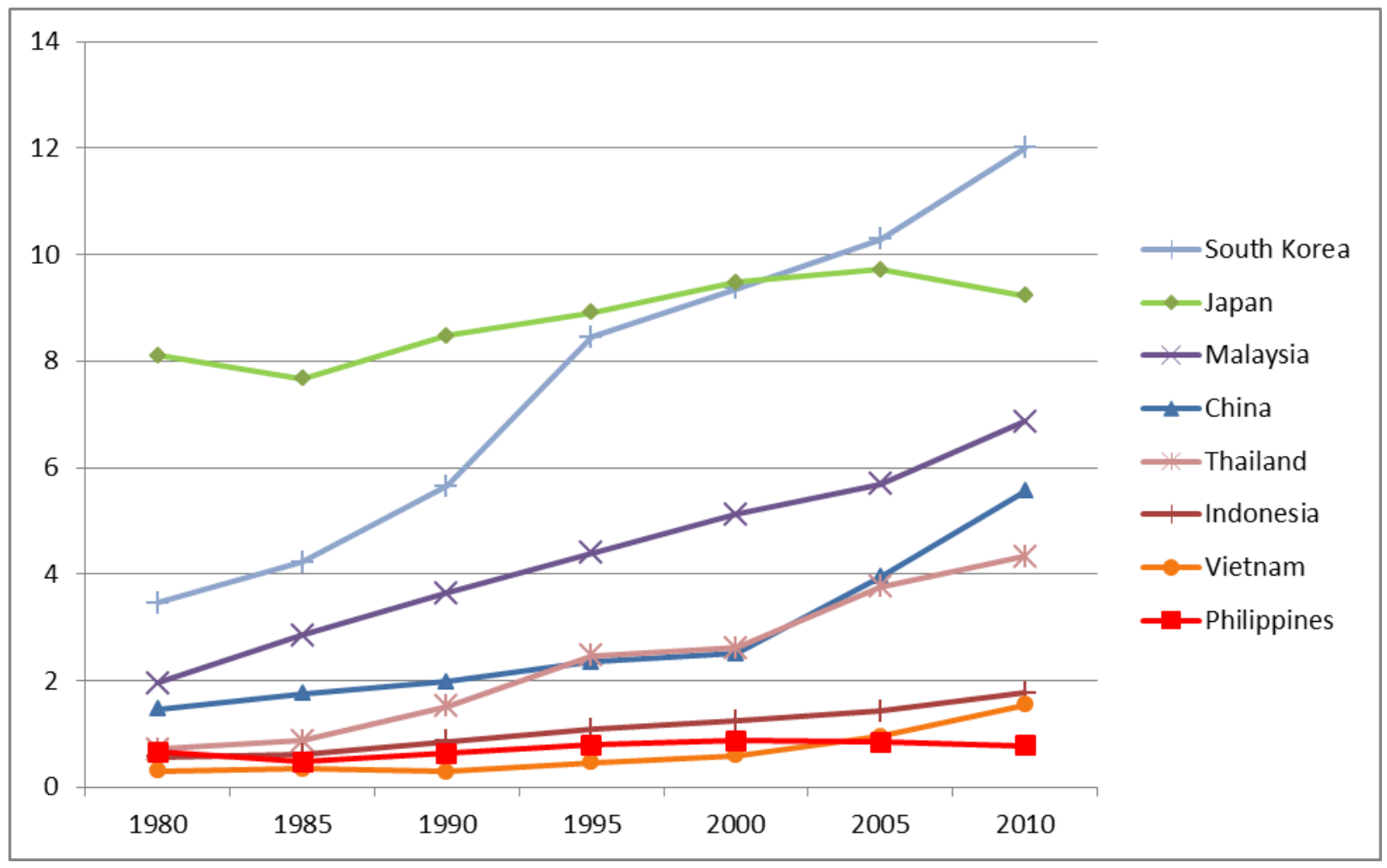


Figure 5: Carbon emissions (in metric tons of carbon equivalents)

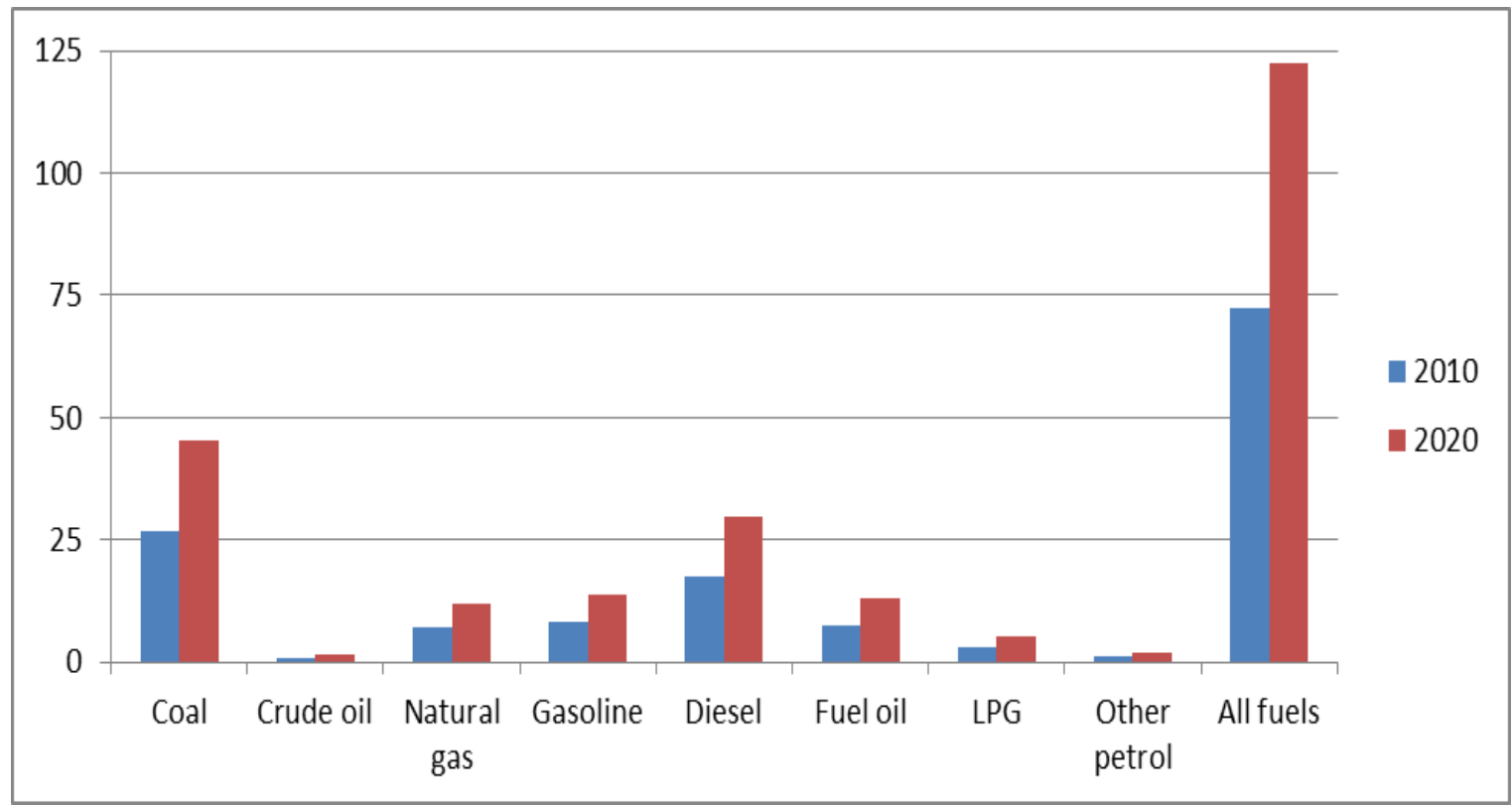

Source: Model database

Figure 6: Carbon emissions by fuel type (cumulative percentage change from 2010)

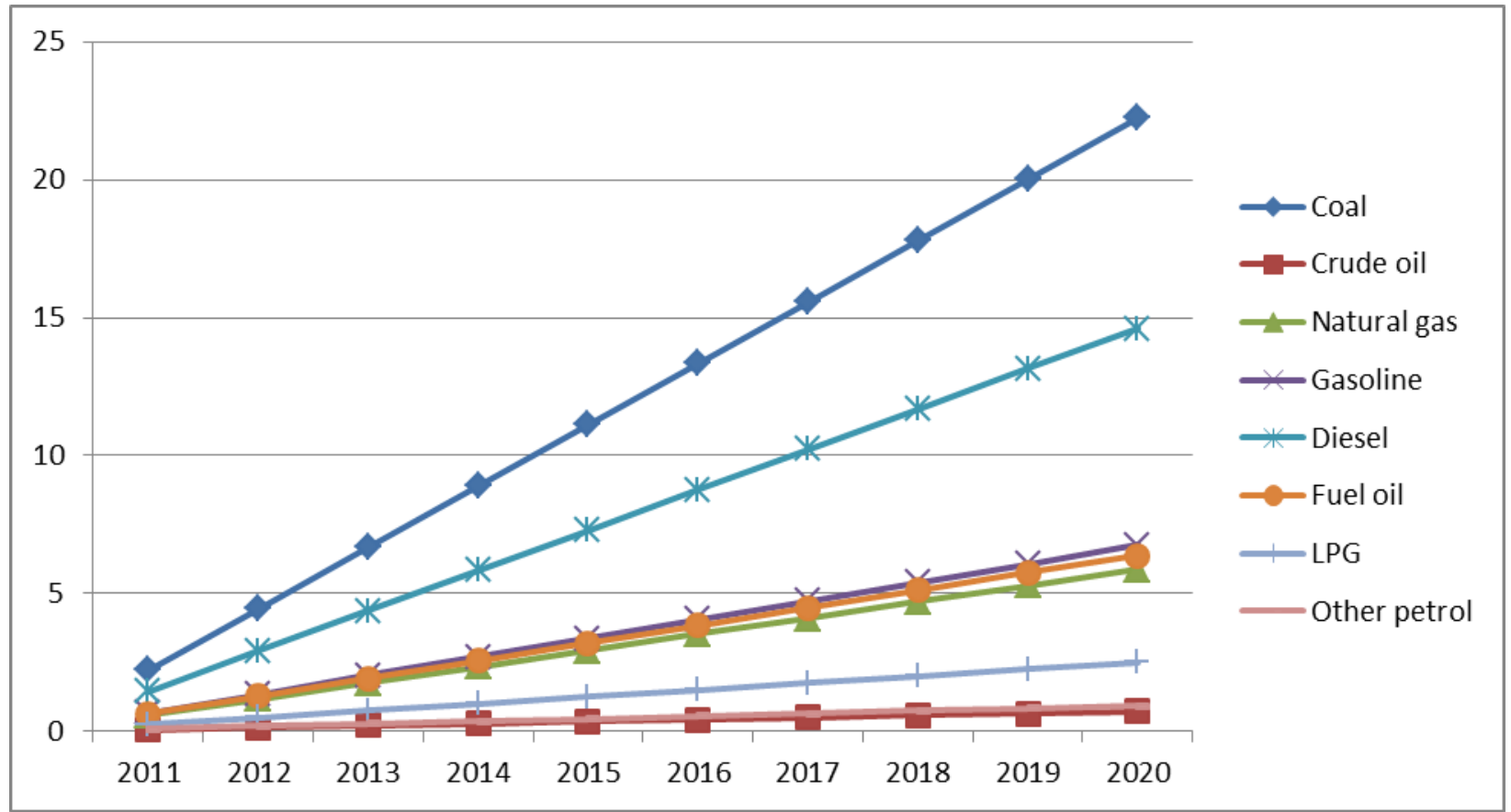

Source: Model database 
Figure 7: Electricity generation by technology (per cent share, 2010)

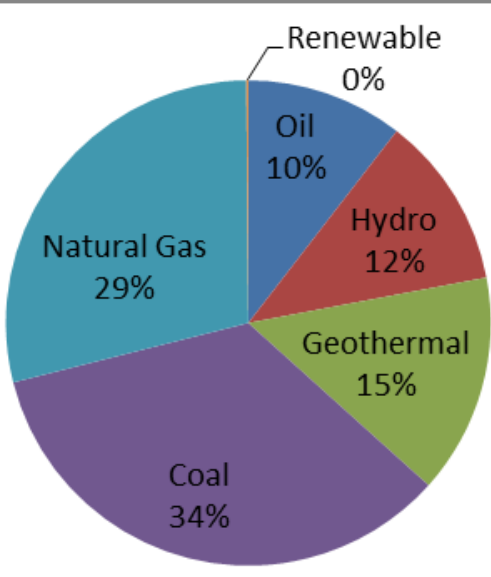

Source: Model database

Table 2: Carbon emissions (cumulative percentage deviation from baseline)

\begin{tabular}{lcr|rr|rr} 
& \multicolumn{2}{c|}{} & \multicolumn{2}{c}{$\begin{array}{c}\text { Energy Efficiency + } \\
\text { Electricity mix }\end{array}$} \\
\cline { 2 - 7 } & \multicolumn{2}{c}{ Carbon Tax } & \multicolumn{2}{c}{ Energy efficiency } & \multicolumn{2}{c}{$\mathbf{2 0 2 0}$} \\
\hline Coal & $\mathbf{2 0 1 5}$ & $\mathbf{2 0 2 0}$ & $\mathbf{2 0 1 5}$ & $\mathbf{2 0 2 0}$ & $\mathbf{2 0 1 5}$ & $\mathbf{2 0 2 0}$ \\
Natural gas & -0.7 & -8.2 & -0.7 & -4.2 & -0.9 & -7.7 \\
Gasoline & 0.0 & 0.5 & -0.2 & -1.0 & -0.1 & -0.4 \\
Diesel & -0.1 & -0.7 & -0.1 & -0.8 & -0.1 & -0.8 \\
Fuel oil & -0.2 & -1.4 & -0.3 & -1.6 & -0.3 & -1.5 \\
LPG & 0.0 & 0.2 & -0.2 & -1.0 & -0.2 & -0.9 \\
Other petrol & 0.0 & -0.2 & 0.0 & 0.1 & 0.0 & 0.2 \\
\hline Total CO2 emissions & 0.0 & 0.0 & 0.0 & 0.1 & 0.0 & 0.1 \\
\hline
\end{tabular}

Source: Simulation results

Table 3: Macro-economic effects (cumulative percentage deviation from baseline)

\begin{tabular}{lrr|rr|rr}
\hline & \multicolumn{2}{c|}{} & \multicolumn{2}{c}{ Energy Efficiency + } \\
& \multicolumn{2}{c}{ Carbon Tax } & \multicolumn{2}{c}{ Energy efficiency } & \multicolumn{2}{c}{\begin{tabular}{c} 
Electricity mix \\
\cline { 2 - 7 }
\end{tabular}} \\
\cline { 2 - 7 } & $\mathbf{2 0 1 5}$ & $\mathbf{2 0 2 0}$ & $\mathbf{2 0 1 5}$ & $\mathbf{2 0 2 0}$ & $\mathbf{2 0 1 5}$ & $\mathbf{2 0 2 0}$ \\
\hline Consumption & -0.1 & -0.6 & 0.2 & 1.7 & 0.2 & 1.7 \\
Investment & -0.1 & -0.6 & 0.1 & 0.8 & 0.1 & 0.8 \\
Government & 0.0 & -0.1 & 0.0 & 0.2 & 0.0 & 0.2 \\
Stocks & 0.0 & 0.1 & 0.0 & 0.2 & 0.0 & 0.2 \\
Exports & 0.0 & 0.2 & -0.1 & -0.7 & -0.1 & -0.6 \\
Imports & 0.1 & 0.4 & -0.1 & -0.4 & -0.1 & -0.3 \\
\hline GDP & -0.1 & -0.6 & 0.3 & 1.8 & 0.3 & 2.0 \\
\hline Employment & -0.1 & -0.6 & 0.2 & 0.9 & 0.2 & 0.9 \\
\hline
\end{tabular}

Source: Simulation results 
Table 4: Economy-wide price effects (cumulative percentage deviation from baseline)

\begin{tabular}{lrr|rr|rr}
\hline & \multicolumn{2}{c|}{ Carbon Tax } & \multicolumn{2}{c|}{ Energy efficiency } & \multicolumn{2}{c}{$\begin{array}{c}\text { Energy Efficiency + } \\
\text { Electricity mix }\end{array}$} \\
\cline { 2 - 7 } & $\mathbf{2 0 1 5}$ & $\mathbf{2 0 2 0}$ & $\mathbf{2 0 1 5}$ & $\mathbf{2 0 2 0}$ & $\mathbf{2 0 1 5}$ & $\mathbf{2 0 2 0}$ \\
\hline Consumer price index & 0.0 & -0.1 & 0.2 & 0.7 & 0.2 & 0.7 \\
Investment price index & -0.1 & -0.4 & 0.2 & 0.8 & 0.2 & 0.8 \\
Government price index & -0.1 & -0.8 & 0.2 & 1.8 & 0.2 & 1.7 \\
Stocks price index & 0.0 & 0.0 & -1.0 & -4.4 & -1.0 & -4.2 \\
Exports price index & 0.0 & -0.1 & 0.1 & 0.4 & 0.1 & 0.4 \\
GDP price deflator & 0.0 & -0.3 & 0.2 & 1.1 & 0.2 & 1.1 \\
Real exchange rate & 0.0 & 0.3 & -0.2 & -1.1 & -0.2 & -1.1 \\
Terms of trade & 0.0 & -0.1 & 0.1 & 0.4 & 0.1 & 0.4 \\
\hline Factor returns & & & & & & \\
\hline Nominal wage & -0.1 & -1.2 & 0.3 & 2.4 & 0.3 & 2.4 \\
Return to capital & -0.4 & -1.3 & 0.6 & 1.9 & 0.6 & 1.9 \\
Return to land & -0.1 & -1.2 & 0.3 & 2.4 & 0.3 & 2.4 \\
\hline Household Income & & & & & & \\
Nominal income & -0.2 & -1.3 & 0.5 & 3.1 & 0.5 & 3.0 \\
Real Income & -0.2 & -1.2 & 0.3 & 2.4 & 0.3 & 2.3 \\
\hline
\end{tabular}

Source: Simulation results 
Table 5: Output level effects (cumulative percentage deviation from baseline)

\begin{tabular}{|c|c|c|c|c|c|c|}
\hline & \multicolumn{2}{|c|}{ Carbon Tax } & \multicolumn{2}{|c|}{ Energy efficiency } & \multicolumn{2}{|c|}{$\begin{array}{c}\text { Energy Efficiency + } \\
\text { Electricity mix }\end{array}$} \\
\hline & 2015 & 2020 & 2015 & 2020 & 2015 & 2020 \\
\hline Paddy rice & 0.0 & -0.1 & 0.0 & 0.2 & 0.0 & 0.2 \\
\hline Corn & 0.0 & -0.1 & 0.0 & 0.2 & 0.0 & 0.2 \\
\hline Fruits and vegetables & 0.0 & 0.0 & 0.0 & 0.1 & 0.0 & 0.1 \\
\hline Other crops & -0.1 & -0.2 & 0.0 & -0.2 & 0.0 & -0.2 \\
\hline Livestock and poultry & -0.1 & -0.6 & 0.2 & 1.2 & 0.2 & 1.2 \\
\hline Other agriculture & -0.1 & -0.4 & 0.1 & 1.0 & 0.1 & 0.9 \\
\hline Mining & -0.1 & -1.0 & 0.3 & 1.4 & 0.3 & 1.4 \\
\hline Coal & -0.5 & -9.7 & -0.2 & -3.3 & -0.4 & -6.0 \\
\hline Crude oil & -0.3 & -1.7 & -0.4 & -2.9 & -0.3 & -2.5 \\
\hline Natural gas & 0.0 & -0.1 & 0.1 & 0.4 & 0.1 & 0.4 \\
\hline Processed food & 0.0 & -0.1 & 0.0 & 0.2 & 0.0 & 0.2 \\
\hline Rice, corn, sugar milling & -0.1 & -0.6 & 0.2 & 1.6 & 0.2 & 1.6 \\
\hline Tobacco and alcohol & 0.0 & -0.2 & 0.1 & 0.7 & 0.1 & 0.8 \\
\hline Textile, garments and footwear & 0.0 & -0.3 & 0.1 & 0.5 & 0.1 & 0.5 \\
\hline Other manufacturing & -0.1 & -0.5 & 0.3 & 2.2 & 0.3 & 2.2 \\
\hline Chemicals & -0.3 & -2.3 & -0.2 & -2.2 & -0.2 & -2.2 \\
\hline Gasoline & -0.3 & -2.6 & 0.3 & 2.1 & 0.3 & 2.2 \\
\hline Diesel oil & 0.0 & -0.1 & 0.0 & -0.3 & 0.0 & -0.3 \\
\hline Fuel oil & 0.0 & -0.3 & 0.0 & 0.0 & 0.0 & 0.0 \\
\hline Liquefied petroleum gas & 0.0 & 0.6 & -0.1 & -1.3 & -0.1 & -1.3 \\
\hline Other petroleum products & 0.6 & 7.9 & -0.5 & 0.2 & 0.2 & 7.7 \\
\hline Metal products & 1.3 & 20.6 & 0.3 & 0.7 & 0.7 & 6.1 \\
\hline Machineries & 0.8 & 14.5 & 0.8 & 2.9 & 1.0 & 6.8 \\
\hline Electric appliances & -1.5 & -22.6 & 0.2 & 0.5 & -0.6 & -11.8 \\
\hline Semi-conductors & 0.2 & 3.0 & 0.2 & 1.9 & 0.7 & 7.8 \\
\hline Electricity-oil & 0.8 & 14.8 & 0.9 & 3.3 & 1.8 & 18.6 \\
\hline Electricity-hydro & -0.1 & -0.8 & 0.2 & 1.2 & 0.2 & 1.3 \\
\hline Electricity-geothermal & 0.3 & 6.2 & -0.6 & -3.8 & -0.5 & -2.5 \\
\hline Electricity-coal & -0.1 & -0.7 & 0.2 & 1.3 & 0.2 & 1.3 \\
\hline Electricity-Natural gas & -0.4 & -3.2 & 0.4 & 3.3 & 0.4 & 3.3 \\
\hline Electricity-renewables & -0.1 & -0.7 & 0.2 & 2.3 & 0.2 & 2.3 \\
\hline Electricity distribution & -0.2 & -2.4 & 0.4 & 3.5 & 0.4 & 3.5 \\
\hline Utilities & 0.0 & -0.8 & 0.1 & 2.1 & 0.1 & 2.1 \\
\hline Retail \& wholesale trade & -0.1 & -0.8 & 0.3 & 2.2 & 0.3 & 2.2 \\
\hline Transport & -0.1 & -0.5 & 0.2 & 1.3 & 0.2 & 1.3 \\
\hline
\end{tabular}

Source: Simulation results 
Table 6: Household effects (cumulative percentage deviation from baseline)

\begin{tabular}{lcc|cr|rr} 
& \multicolumn{2}{c|}{ Carbon Tax } & \multicolumn{2}{c|}{ Energy efficiency } & \multicolumn{2}{c}{$\begin{array}{c}\text { Energy Efficiency + } \\
\text { Electricity mix }\end{array}$} \\
\hline Nominal Income & $\mathbf{2 0 1 5}$ & $\mathbf{2 0 2 0}$ & $\mathbf{2 0 1 5}$ & $\mathbf{2 0 2 0}$ & $\mathbf{2 0 1 5}$ & $\mathbf{2 0 2 0}$ \\
\hline Rural & & & & & & \\
Urban & -0.16 & -1.25 & 0.50 & 3.05 & 0.49 & 3.01 \\
\hline Consumer price index & -0.17 & -1.32 & 0.50 & 3.04 & 0.49 & 3.01 \\
\hline Rural & & & & & & \\
Urban & -0.01 & -0.09 & 0.16 & 0.69 & 0.15 & 0.65 \\
Real Income & -0.02 & -0.10 & 0.19 & 0.69 & 0.18 & 0.65 \\
\hline Rural & & & & & & \\
Urban & -0.15 & -1.16 & 0.34 & 2.36 & 0.34 & 2.36 \\
\hline Source: Simulation results & -0.15 & -1.22 & 0.31 & 2.35 & 0.31 & 2.37 \\
\hline
\end{tabular}

